\title{
High-Performance Work Practices and Organizational Innovativeness: The Roles of Relational Coordination Competencies and Market Turbulence as a Mediator or Moderator
}

\author{
Seung-Yoon Rhee ${ }^{1}{ }^{(}$, Jooyeon Park ${ }^{2}\left(\mathbb{D}\right.$ and Hyung-Deok Shin ${ }^{1, *}$ \\ 1 Department of Business Administration, Hongik University, Seoul 04066, Korea; syrhee@hongik.ac.kr \\ 2 Department of Design Management, Hongik University, Seoul 04066, Korea; wndusl8888@naver.com \\ * Correspondence: shinhd@hongik.ac.kr; Tel.: +82-2-320-1724
}

Received: 19 July 2020; Accepted: 10 September 2020; Published: 14 September 2020

\begin{abstract}
Despite an enduring interest in the effect of high-performance work practices (HPWP) on organizational outcomes, relatively little is known about how the human resources practices that engage employees in a coordinated effort foster relational coordination competencies, and further enhance organizational innovativeness. Drawing on the relational model of HPWP, this study examined the impact of HPWP on organizational innovativeness through employees' relational coordination competencies, and the moderating effect of environmental volatility on the relationship. Using two-wave panel data from 301 manufacturing companies in South Korea, the results showed that HPWP positively influenced organizational innovativeness, as measured by the number of patent applications with a 6-year time lag, and that the link was partially mediated by employees' relational coordination competencies. The positive effect of HPWP on organizational innovativeness was more pronounced when market turbulence was high. This study adds value to the HPWP literature by revealing the importance of human resource practices that develop employees' relational coordination and communication competencies in achieving organizational innovativeness. Such practices are becoming even more crucial in today's complex business environment, which necessitates task integration and employee cooperation.
\end{abstract}

Keywords: high-performance work practices; relational coordination; innovativeness; market turbulence

\section{Introduction}

The idea that human capital is a primary source of firm competitive advantage has increasingly gained prominence [1,2]. The focus on human capital has led to an increased attention to high-performance work practices (HPWP) as ways to enhance the value of human capital [3]. With an emphasis on high-commitment, high-involvement human resource (HR) strategies, the notion of HPWP involves "a group of separate but interconnected HR practices that together recruit, select, develop, motivate, and retain employees" [3] (p. 77).

Researchers have revealed positive effects of HPWP on organizational outcomes such as productivity, sales volume and financial performance $[1,4,5]$. Several lines of research have further explored the causal mechanisms underlying the link between HPWP and firm performance $[6,7]$. One perspective takes an approach that HPWP contribute to firm performance by increasing the value of human capital through the hiring of high-caliber candidates and developing their knowledge and skills $[8,9]$. HPWP, including selective hiring, rigorous training, competitive compensation which also helps recruiting, and job rotation as an opportunity to learn, altogether ensure the attainment 
of high-quality human capital. Prior studies have established the human capital and performance link $[10,11]$.

A relatively new and underexplored perspective suggests that HPWP enhance firm performance by engaging employees in a coordinated effort and facilitating cooperation [6]. Termed as relational coordination, this approach posits seven components that facilitate the coordination of highly interdependent work: communication that is frequent, timely and accurate and focused on problemsolving instead of blaming, and work relationships based on shared goals and knowledge and mutual respect [12]. This perspective is particularly relevant to today's business environment, which necessitates task integration and employee cooperation. Extant research has associated relational coordination with quality, efficiency and productivity $[13,14]$.

We combine these two perspectives and explore how HPWP that foster relational coordination and cooperation among employees increase the value of human capital in the form of enhanced competencies. We further examine how HPWP may strengthen organizational innovativeness directly and indirectly through increased employee relational coordination competencies. Despite the enduring interest in the impact of HR practices on organizational outcomes, only a few studies have investigated the relationship between HR practices and organizational creativity and innovativeness [15,16]. Moreover, by specifically focusing on HPWP that facilitate coordination and cooperation, we reveal the importance of employee relational coordination competencies in achieving organizational innovativeness, a critical yet underexplored question. Research has shown that the need for relational coordination is particularly acute in settings characterized by interdependence, uncertainty and time constraints [14], which corresponds to the organizational innovation situation. In the increasingly unpredictable, fast-changing business environment, firms equipped with innovative capabilities are the most likely to survive, which all the more necessitates firms' capacity for effective relational coordination.

We further extend our argument by examining the condition that strengthens the positive relationship between HPWP and organizational innovativeness. Drawing on the contingency and interactional perspectives that emphasize consideration of situational factors in explaining the effects of organizational characteristics on outcomes $[17,18]$, we explore the mediating effect of market turbulence. Extant research shows that turbulent market conditions necessitate firms to innovate in order to meet evolving market needs [19]. We therefore assume that the positive effect of HPWP on organizational innovativeness would be more pronounced under the volatile environmental settings.

This study contributes to the HPWP literature in two ways. First, by incorporating both relational coordination and increased human capital value perspectives through which HPWP lead to organizational outcomes [6,8], we reveal how the two perspectives can together explain the positive effects of HPWP on organizational innovativeness. Second, although market turbulence has been found to be an external situational factor that has a profound impact on organizations, we only have limited understanding of its effects in association with HPWP. We fill this gap by uncovering how turbulent market conditions strengthen the positive effect of HPWP on organizational innovativeness.

In the following sections, we present the conceptual background with a focus on HPWP and the relational coordination approach. We then propose that HPWP foster organizational innovativeness through employee relational coordination competencies. We further suggest that firms facing turbulent market conditions will exhibit stronger association between HPWP and organizational innovativeness. The next part will elaborate on the research methods and the results of the analyses. The final section will provide a discussion of our findings, highlighting theoretical and practical implications as well as future research directions.

\section{Theoretical Background and Hypotheses Development}

\subsection{High-Performance Work Practices (HPWP)}

The notion of HPWP focuses on increasing employee productivity through empowerment and shared goals and information, instead of managing through rules and regulations [9]. It indicates 
successful HR practices implemented in bundles including effective performance evaluation, clear performance-reward linkage, high-quality training, and decentralized decision-making [20]. In particular, a growing interest is in understanding the causal mechanisms underlying the relationship between HPWP and organizational outcomes $[3,6]$. Such interest is based on the assumption that HR practices per se do not create value for organizations. Rather, it is the human resources trained and motivated through effective HPWP that add value and bring performance gains to the organization [9].

One of the key mechanisms through which HPWP help organizations achieve performance goals pertains to increased knowledge and skills of employees. The theory of human capital together with the resource-based view of the firm suggest that effective training and career development practices tend to enhance the value of human capital [8], which becomes a primary resource for sustainable firm competitive advantage [21]. For instance, effective selection and HR development practices have been associated with increased collective human capital [9] and firm performance [10,11,22].

A relatively new and underexplored perspective by Gittell and colleagues [6,14] proposes relational coordination among employees and across diverse units as another important mechanism underlying the link between HPWP and organizational outcomes. Relational coordination refers to "a mutually reinforcing process of interaction and communication, and relationships carried out for the purpose of task integration" [23] (p. 301). Key components of relational coordination include work relationships characterized by shared goals and knowledge and mutual respect together with frequent, timely and accurate communication that is focused on problem-solving rather than blaming [12]. Work relationships with such qualities are likely to enable and motivate employees to engage in a collaborative endeavor with efficiency and heightened productivity [6]. More specifically, shared goals and knowledge enable employees to heed to the overall work process and to communicate across diverse functions in a timely way with greater accuracy. In addition, employees engaged in relational coordination tend to respect the contributions of others and be receptive to communication regardless of relative status, which, in turn, reinforces knowledge sharing and efficient coordination.

Certain HR practices have been noted to foster relational coordination such as interpersonal and inter-unit relationship building, close coordination and collaboration, training for teamwork, shared accountability and rewards, and collective brainstorming activities [6]. A body of research has shown positive associations between these HR practices and organizational outcomes. For instance, extensive communication between labor and management resulted in higher productivity [24], and HR practices that encouraged the development of top management team social networks increased firm performance [25].

We take the above two perspectives-theories of human capital and relational coordination-in explaining how HPWP can contribute to organizational outcomes. Our assumption rests on the idea that the potential value of human capital cannot be realized fully unless employees coordinate and collaborate with each other and achieve synergistic benefits. Given today's business environment with increasing complexity and uncertainty, a deeper understanding of both pathways (i.e., relational coordination and increased value of human capital) through which HPWP result in organizational outcomes is warranted.

\subsection{HPWP and Organizational Innovativeness}

Prior research has revealed that HPWP are associated with positive organizational outcomes such as increased productivity, sales volume and financial performance [4,26,27]. In this study, we specifically focus on organizational innovativeness as a key outcome of HPWP. Organizational innovativeness refers to "the newness and meaningfulness of a firm's whole range of products" [16] (p. 925), which "implies a firm being proactive by exploring new opportunities rather than merely exploiting current strengths" [28] (p. 65). We contend that HPWP enhance organizational innovativeness through relational coordination and collaboration among employees and across diverse units for a number of reasons. One of the key features of HPWP is internal knowledge and information dissemination through practices such as job rotation, decentralized decision-making and shared information systems $[4,13]$. 
Because employees are aware of interdependencies and collaborative opportunities in the organization, they are more likely to conceive ideas for innovation [29]. Frequent problem-solving communication based on shared knowledge and information can speed up the idea development and implementation processes as well [15]. Considering that key innovations often result from idea-generation and cooperation that cut across organizational boundaries, HPWP with a focus on engaging employees in a coordinated and collaborative effort are indeed highly likely to foster organizational innovativeness. Thus, we hypothesize the following:

Hypothesis 1 (H1). HPWP will increase organizational innovativeness.

\subsection{Effect of HPWP on Organizational Innovativeness via Employee Relational Coordination Competencies}

The human capital perspective of HPWP posits that effective HR practices are expected to enhance organizational outcomes by developing employee knowledge and skills [8,9]. We take this perspective and suggest employee relational coordination competencies as a key mechanism between HPWP and organizational innovativeness. We further propose that the human capital perspective can be conceived together with the relational coordination perspective based on the assumption that HPWP with a focus on facilitating relational coordination among employees are particularly crucial in developing sustainable employee competencies. Especially in innovative organizations where tasks are highly interdependent, uncertain and time-constrained [30], the relational focus of HPWP is likely to strengthen the requisite competencies of employees, and, in turn, increase organizational innovativeness.

Our theorization that the effect of HPWP on organizational innovativeness is mediated by employee relational coordination competencies is based on the premise that the patterns of work interactions and relationships are fundamentally shaped by organizational systems and structures [31]. For example, bureaucratic structures and systems tend to reinforce fragmentation by functions whereas systems and structures related to HPWP are likely to strengthen cross-functional networks and further build the relational coordination competencies of employees. More specifically, evaluation and reward systems based on cross-functional performance, work processes that span functional boundaries, and job rotation across diverse functional areas can be considered as examples of HPWP that foster relational coordination and related competencies among employees.

HR practices with a relational focus such as team-based training, cross-divisional knowledge sharing and participative decision-making, tend to develop the skills and knowledge required for highly interdependent, collaborative tasks [15]. For example, during team-based training sessions, employees frequently engage in collective brainstorming and decision-making activities, which likely increase collaborative problem-solving skills and knowledge of employees [7]. Shared goals are expected to motivate employees to engage in collaborative effort and contribute their ideas in order to achieve the goals [32], thus developing the skills and knowledge required for performing highly interdependent tasks [33]. These sets of collective communication and problem-solving skills are likely to promote the sharing of ideas and knowledge, which frequently results in improved solutions [3] and innovative ideas. In order to achieve desired organizational outcomes in highly interdependent and uncertain situations with time constraints, which corresponds to the process of innovation, it is necessary for firms to hinge on employees' competencies to coordinate and mutually adjust to each other's actions. Such competencies enable employees to make rapid real-time adjustments as soon as new information emerges [31] and make amendments to their innovative processes or products. Thus, our second hypothesis is as follows:

Hypothesis 2 (H2). Employee relational coordination competencies will mediate the relationship between HPWP and organizational innovativeness, such that HPWP will be positively related to employee relational coordination competencies, which in turn will be positively related to organizational innovativeness. 


\subsection{The Moderating Effect of Market Turbulence}

While mounting evidence shows the positive outcomes of HPWP [1,4,5], we have little understanding of the impact that market environment may have on the relationship between HPWP and organizational outcomes. According to the contingency perspective, the extent to which HR practices result in desirable organizational outcomes depends on contextual factors including the organizational strategy and business environment [17]. When the chosen HR practices fit well with contextual factors of the firm such as its strategy to survive in a highly competitive market, a better performance outcome is expected. In our case, firms facing volatile business environments are likely to compete with innovative ideas and products and may implement HR practices that reinforce idea generation and cross-functional collaboration for innovative projects. As far as such HR practices fit with the firm's strategic orientation toward innovation, they are expected to result in desired outcomes. Drawing additionally on the interactional perspective that suggests the importance of considering situational factors in explaining the effects of organizational characteristics on outcomes [18], we explore how market turbulence may influence the link between HPWP and organizational innovativeness.

A turbulent market refers to "frequent and unpredictable changes in product preferences and customer needs, in product and production technologies, and in the competitive landscape" [34] (p. 1930). Due to the constant changes in customer preferences and technologies, it is imperative for firms to engage in ongoing innovative activities [19]. Market turbulence thus triggers a strong recognition of the need to innovate [35], and encourages an organization-wide innovation effort. In this circumstance, the interpersonal and inter-unit coordination orientation of HPWP can lead to a stronger propensity to innovate. Through shared goals, participative decision-making, and cross-divisional knowledge sharing and collaboration, HPWP may speed up the innovation processes by tracking and sharing information about market changes [35] and by taking advantage of the well-established coordination and collaboration practices for innovative outcomes. Hence, we hypothesize as follows:

Hypothesis 3 (H3). Market turbulence will strengthen the positive relationship between HPWP and organizational innovativeness

Figure 1 depicts our research model.

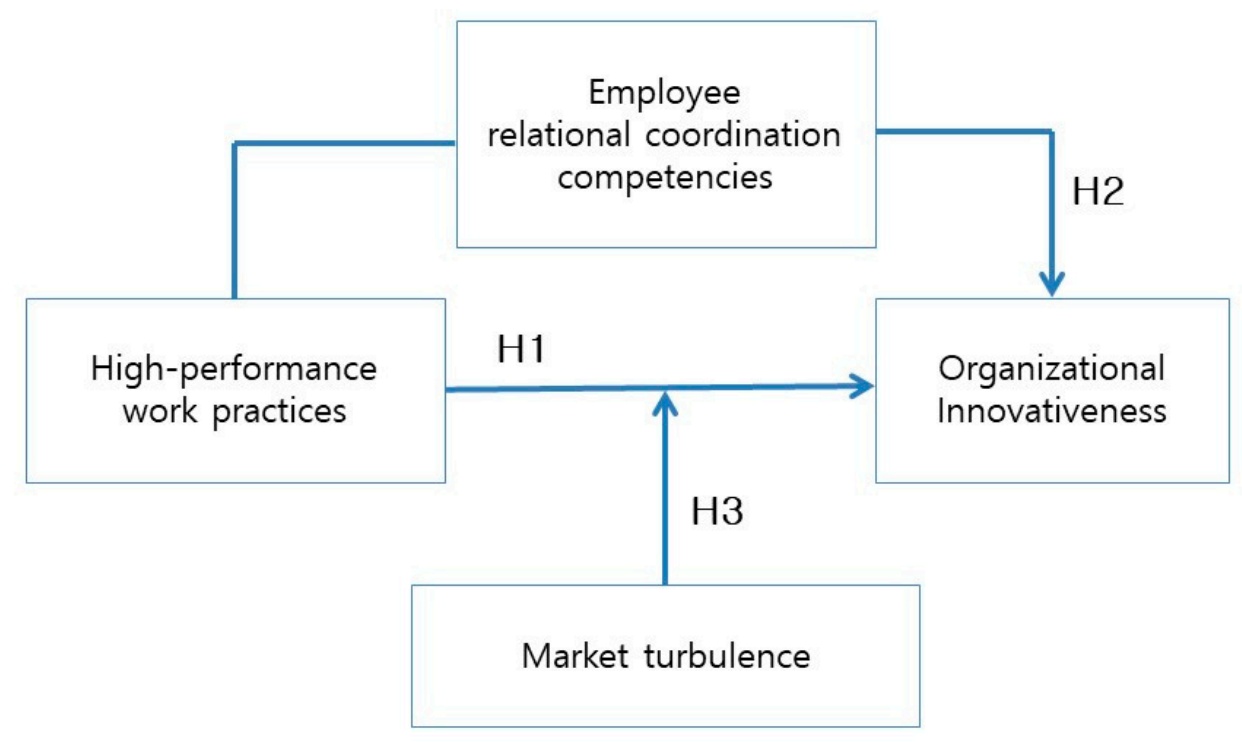

Figure 1. Research Model. 


\section{Methods}

\subsection{Data Collection}

Empirical data were obtained from the 3rd and 6th Human Capital Corporate Panel Survey (HCCP) conducted in 2009 and 2015, respectively, by the Korea Research Institute for Vocational Education and Training (KRIVET) and by the Korean Intellectual Property Office. This survey was intended to diagnose the current status or trends of HR management and corporate strategies and outcomes in Korea. The survey population consisted of corporations with more than 100 workers and listed in Korea Information Service (KIS) Corporate Data 2005. A total of 473 firms in the manufacturing sector participated in the survey, and we used data from 301 firms that had R\&D units. We focused on the firms in the manufacturing sector with $R \& D$ units where organizational innovativeness was relevant and critical. Innovative manufacturing firms around the world have been reported to adopt organization-wide quality management tools and techniques, which often lead to the development and launch of new processes and innovative products [36].

The multi-source HCCP data set asked each corporate director and manager to respond to a separate section in the survey of each company. For instance, human resource management (HRM) managers responded to items related to HRM systems whereas human resource development (HRD) managers answered training-related and employee competencies items. Overall business, strategy and firm environment information was obtained from strategic planning directors.

\subsection{Measurement}

Organizational innovativeness. We measured organizational innovativeness by counting the number of patent applications in the year 2015 based on the data provided by the Korean Intellectual Property Office. The time point of 2015 is about six years after HPWP, employee relational coordination competencies and market turbulence were measured using the 2009 HCCP data set.

High-performance work practices. Six categories of HPWP were measured based on Gittell and colleagues' study [6] (see Table 1). We took the average score of the six categories because each category interacts with each other, and a synergistic effect was expected [20].

Employee relational coordination competencies. We measured employee relational coordination competencies as the average of communication skills, resource utilization skills and interpersonal skills. The Cronbach alpha was 0.76 .

Market turbulence. We measured market turbulence as the average of market innovativeness, market leader strategy, and emphasis on new product development. The Cronbach alpha was 0.6.

Control variables. Firm size, foreign ownership, strategic alliance and corporate governance variables were included to control for the effects on the number of patent applications. The firm size of less than 300 employees is regarded as an SME (coded as ' 0 '), and that of more than 300 was coded as ' 1 '. Foreign investment has been found to influence firm performance. Therefore, firms with foreign ownership were coded as ' 1 ' and otherwise ' 0 '. Corporate governance is divided into firms run by owners and those run by professional executives. If the owner managed the entire firm or the owner's involvement in management was considerably large, we coded it as ' 0 '. If professional executives completely managed the firm with little involvement of the owner, we coded it as ' 1 '. Finally, strategic alliances tend to enhance firms' creative performance by fostering cooperation between firms. Therefore, firms with strategic alliances are coded as ' 1 ' and otherwise ' 0 '. Table 1 displays measurement items of study variables, and Table 2 shows means, standard deviations and correlations for the variables. 
Table 1. Study variables and measurement items.

\begin{tabular}{|c|c|c|c|}
\hline \multicolumn{2}{|c|}{ Variables } & Measurement Items & \multirow{2}{*}{$\begin{array}{c}\text { Source of Data } \\
\text { Data provided by Korean } \\
\text { Intellectual Property Office } \\
\text { in } 2015\end{array}$} \\
\hline $\begin{array}{l}\text { Dependent } \\
\text { variable }\end{array}$ & $\begin{array}{l}\text { organizational } \\
\text { innovativeness }\end{array}$ & number of patent applications & \\
\hline \multirow{20}{*}{$\begin{array}{l}\text { Independent } \\
\text { variable } \\
\text { (HPWP) }\end{array}$} & \multirow{2}{*}{$\begin{array}{l}\text { reduction in hierarchical } \\
\text { levels }\end{array}$} & reduction in hierarchical levels & \multirow{13}{*}{$\begin{array}{c}\text { Responded by HRM } \\
\text { managers in the } 2009 \\
\text { HCCP data set }\end{array}$} \\
\hline & & abolition of positions & \\
\hline & \multirow{2}{*}{ evaluation system } & 360-degree performance evaluation & \\
\hline & & participatory goal setting & \\
\hline & \multirow{4}{*}{ incentive system } & employee stock ownership plan & \\
\hline & & stock option & \\
\hline & & profit sharing & \\
\hline & & gainsharing & \\
\hline & \multirow{3}{*}{$\begin{array}{l}\text { cross-departmental R\&D } \\
\text { practices }\end{array}$} & $\begin{array}{c}\text { cross-departmental collaboration on R\&D } \\
\text { activities }\end{array}$ & \\
\hline & & $\begin{array}{c}\text { cross-departmental collaboration on process } \\
\text { improvement }\end{array}$ & \\
\hline & & $\begin{array}{l}\text { cross-departmental training on } \mathrm{R} \& \mathrm{D} \text { and } \\
\text { process improvement }\end{array}$ & \\
\hline & \multirow{2}{*}{$\begin{array}{c}\text { organizational change } \\
\text { with a focus on } \\
\text { cooperation }\end{array}$} & introduction of knowledge sharing practices & \\
\hline & & introduction of cross-departmental integration & \\
\hline & \multirow{7}{*}{ training system } & collective internal training & \multirow{7}{*}{$\begin{array}{l}\text { Responded by HRD } \\
\text { managers in the } 2009 \\
\text { HCCP data set }\end{array}$} \\
\hline & & collective external training & \\
\hline & & mentoring & \\
\hline & & communities of practice & \\
\hline & & on-the-job training & \\
\hline & & job rotation & \\
\hline & & training collaboration with subcontractors & \\
\hline \multirow{3}{*}{$\begin{array}{l}\text { Mediating } \\
\text { variable }\end{array}$} & \multirow{3}{*}{$\begin{array}{l}\text { employee relational } \\
\text { coordination } \\
\text { competencies }\end{array}$} & communication skills & \multirow{3}{*}{$\begin{array}{l}\text { Responded by HRD } \\
\text { managers in the } 2009 \\
\text { HCCP data set }\end{array}$} \\
\hline & & resource utilization skills & \\
\hline & & interpersonal skills & \\
\hline \multirow{3}{*}{$\begin{array}{l}\text { Moderating } \\
\text { variable }\end{array}$} & \multirow{3}{*}{ market turbulence } & market innovativeness & \multirow{7}{*}{$\begin{array}{l}\text { Responded by strategic } \\
\text { planning directors in the } \\
2009 \text { HCCP data set }\end{array}$} \\
\hline & & market leader strategy & \\
\hline & & emphasis on new product development & \\
\hline \multirow{4}{*}{ Control variables } & firm size & number of employees over 300 or else & \\
\hline & foreign ownership & foreign ownership & \\
\hline & corporate governance & $\begin{array}{l}\text { firms run by owner or by professional } \\
\text { executives }\end{array}$ & \\
\hline & strategic alliance & strategic alliance & \\
\hline
\end{tabular}

Table 2. Means, standard deviations and correlations.

\begin{tabular}{|c|c|c|c|c|c|c|c|c|c|}
\hline Variables & Mean & s.d. & 1 & 2 & 3 & 4 & 5 & 6 & 7 \\
\hline 1. organizational innovativeness & 32.91 & 143.55 & - & & & & & & \\
\hline 2. high-performance work practices & 7.88 & 2.85 & $0.292 * *$ & - & & & & & \\
\hline 4. market turbulence & 2.22 & 0.58 & $0.165^{* *}$ & $0.273 * *$ & $0.098+$ & - & & & \\
\hline 5. firm size & 0.53 & 0.50 & $0.186^{* *}$ & $0.168^{* *}$ & $0.141 *$ & 0.037 & - & & \\
\hline 8. strategic alliance & 0.22 & 0.42 & $0.164^{* *}$ & $0.200 * *$ & -0.006 & $0.140 * *$ & $0.115 *$ & $0.127 *$ & $0.100+$ \\
\hline
\end{tabular}




\section{Results}

The variance inflation factors (VIF) showed that no correlations were above 1.0. Thus, all the variables are included in the analysis. Table 3 presents the main regression results. The baseline model (M0) contains control variables, which are all significant at $p<0.05$. M1 shows that the effect of HPWP on number of patent applications is positive and significant $(\beta=11.974, p<0.01)$; thus, Hypothesis 1 is supported. Further, market turbulence has a positive moderation effect $(\beta=13.135$, $p<0.01$ ), thereby supporting Hypothesis 3 . F-values of all three models are significant and adjusted Rsquared values are acceptable, indicating that the multivariate regression models are robust.

Table 3. Regression results for $\mathrm{H} 1$ and $\mathrm{H} 3$.

\begin{tabular}{|c|c|c|c|}
\hline & M0 & M1 & M2 \\
\hline constant & $\begin{array}{c}-22.071+ \\
(13.171)\end{array}$ & $\begin{array}{c}-106.347^{* *} \\
(23.532)\end{array}$ & $\begin{array}{c}96.096 \\
(89.144)\end{array}$ \\
\hline firm size & $\begin{array}{l}34.188 * \\
(16.575)\end{array}$ & $\begin{array}{c}25.388 \\
(16.244)\end{array}$ & $\begin{array}{c}25.892 \\
(16.066)\end{array}$ \\
\hline foreign ownership & $\begin{array}{l}39.616 * \\
(16.830)\end{array}$ & $\begin{array}{l}38.652 * \\
(16.362)\end{array}$ & $\begin{array}{l}36.647 * \\
(16.181)\end{array}$ \\
\hline corporate governance & $\begin{array}{l}39.302 * \\
(17.862)\end{array}$ & $\begin{array}{l}33.484+ \\
(17.417)\end{array}$ & $\begin{array}{l}32.486+ \\
(17.360)\end{array}$ \\
\hline strategic alliance & $\begin{array}{l}41.699 * \\
(19.360)\end{array}$ & $\begin{array}{c}27.318 \\
(19.119)\end{array}$ & $\begin{array}{c}25.884 \\
(18.951)\end{array}$ \\
\hline market turbulence & & & $\begin{array}{c}-86.950 * \\
(39.368)\end{array}$ \\
\hline HPWP & & $\begin{array}{l}11.974 * * \\
(2.805)\end{array}$ & $\begin{array}{c}-18.977+ \\
(11.115)\end{array}$ \\
\hline $\mathrm{HPWP} \times$ market turbulence & & & $\begin{array}{c}13.135 * * \\
(4.681)\end{array}$ \\
\hline $\mathrm{F}$ & $7.482 * *$ & $9.978^{* *}$ & $8.621 * *$ \\
\hline $\operatorname{adj} R^{2}$ & 0.080 & 0.130 & 0.151 \\
\hline
\end{tabular}

As shown in Tables 4 and 5, we performed two tests to investigate the mediation effect of employee relational coordination competencies between HPWP and the number of patent applications. First, we followed the three-step analysis procedure [37] (Table 4). In the first step, we found that HPWP was positively and significantly associated with the number of patent applications ( $\beta=11.974, p<0.01$ ). In the second step, the mediator (employee relational coordination competencies) was positively and significantly associated with HPWP $(\beta=0.030, p<0.01)$. In the third step, the mediator had a significant effect on the number of patent applications, even after controlling for the effect of HPWP ( $\beta=10.966, p<0.01)$. The value of $\beta$ between HPWP and number of patent applications decreased from the first step to the third step, indicating a partial mediation effect of employee relational coordination competencies. Hence, Hypothesis 2 was partially supported.

In addition, we conducted a bootstrapping analysis to confirm the mediation effect of employee relational coordination competencies. Bootstrapping uses the information gathered through a number of resamplings to estimate the distribution of population [38]. The number of resamplings for bootstrapping was 5000, and we used a bias-corrected confidence intervals method. The mediation effect was significant because the $95 \%$ confidence interval (CI) did not include 0 (upper level CI (ULCI): 3.186; lower level CI (LLCI): 0.204). Table 5 presents the bootstrapping analysis results. 
Table 4. Mediation analysis results for $\mathrm{H} 2$.

\begin{tabular}{|c|c|c|c|c|c|}
\hline & Step Path & $\mathrm{B}(\mathrm{SE})$ & $\mathbf{p}$ & $\mathbf{F}$ & $\mathbf{R}^{2}$ \\
\hline 1 & HPWP $\rightarrow$ organizational innovativeness & $\begin{array}{l}11.974^{* *} \\
(2.805)\end{array}$ & 0.000 & $9.978^{* *}$ & 0.130 \\
\hline 2 & $\begin{array}{l}\text { HPWP } \rightarrow \text { employee relational coordination } \\
\text { competencies (a) }\end{array}$ & $\begin{array}{l}0.030 * * \\
(0.011)\end{array}$ & 0.008 & $3.176^{* *}$ & 0.035 \\
\hline \multirow[t]{2}{*}{3} & $\mathrm{HPWP} \rightarrow$ organizational innovativeness & $\begin{array}{l}10.966 * * \\
(2.871)\end{array}$ & 0.000 & \multirow[t]{2}{*}{$9.352 * *$} & \multirow[t]{2}{*}{0.143} \\
\hline & $\begin{array}{l}\text { Employee relational coordination } \\
\text { competencies } \rightarrow \text { organizational innovativeness (b) }\end{array}$ & $\begin{array}{l}33.165^{*} \\
(14.183)\end{array}$ & 0.020 & & \\
\hline
\end{tabular}

Note: ${ }^{*} p<0.05 ;{ }^{* *} p<0.01 ; \mathrm{N}=301$.

Table 5. Bootstrapping of the mediation effect of employee relational coordination competencies.

\begin{tabular}{cccc}
\hline \multirow{2}{*}{ Mediating Effect Coefficients } & \multirow{2}{*}{ Boot. SE. } & \multicolumn{2}{c}{ 95\% Confidence Interval } \\
\cline { 3 - 4 } & & Boot. LLCI & Boot. ULCI \\
\hline 0.995 & 0.645 & 0.204 & 3.186 \\
\hline
\end{tabular}

\section{Discussion: The Relation among HPWP, Relational Coordination Competencies, Market Turbulence and Open Innovation}

The present study investigated the effect of HPWP on organizational innovativeness through employee relational coordination competencies, and examined how market turbulence strengthened the positive relationship between HPWP and organizational innovativeness.

We found that HPWP positively influenced organizational innovativeness measured by the number of patent applications with a 6-year time lag, and that the link was partially mediated by employees' relational coordination competencies. HPWP with a relational focus puts emphasis on cross-functional cooperation and the sharing of knowledge and goals, which allows efficient detection of customer demand, continued improvement of innovation processes, and creative idea generation and implementation. These altogether have been found essential to product and process innovation [39] and to organizational innovativeness in our case. Our finding underscores the importance of developing employee skills and knowledge required for highly interdependent, collaborative tasks with uncertainty and time-constraints. HPWP involving training sessions with collective brainstorming and problem-solving, cross-departmental R\&D practices, collective incentive systems and knowledge and goal sharing cultivate employee competencies for coordination and mutual adjustment, which leads to organizational innovativeness. With the advancement of open platforms and information technology, a growing number of firms engage in open innovation practices through which internal and external resources are absorbed and combined [40]. Employees' relational coordination competencies can play an important role in the open innovation context by facilitating cross-organizational or cross-societal coordination and collaboration.

In addition, our results revealed that the positive effect of HPWP on organizational innovativeness was more pronounced when market turbulence was high. Since market turbulence triggers a strong need to innovate [35], organizations with HPWP are more likely to readily engage in interpersonal and inter-unit coordination and a collaborative effort for innovation, thus leading to organizational innovativeness. HR practices including cross-departmental knowledge sharing, collective training and participative decision-making may speed up the innovative processes especially under the volatile market environment by orienting employees' collective efforts toward innovation. 


\section{Conclusions}

\subsection{Theoretical Implications}

The findings from our study contribute to the HPWP and relational coordination literature in several ways. First, we integrated the two mechanisms that explain how HPWP influence firm performance, one by increased value of human capital through knowledge and competency development [8], and the other by increased coordination and cooperation [6]. Combining these two perspectives, we proposed that HPWP foster relational coordination and cooperation practices among employees, which leads to employee relational coordination competencies. Consistent with the human capital approach to HPWP [8], the current study argued that it is not the HRM system per se that leads to organizational outcomes. It is rather the work practices and employee competencies enabled and nurtured through the HRM system that bring about tangible organizational outcomes. By integrating the two approaches to HPWP and proposing employee relational coordination competencies as a critical explanatory mechanism, this study attempted to expand the vast body of literature on HPWP and relational coordination. Furthermore, we verified the importance of relational coordination competencies in the context of the manufacturing industry with an $R \& D$ and innovation focus. This finding adds to the extant studies on relational coordination conducted mostly in the healthcare [41-44] and airline industries [45] as well as in the financial services industry [46].

Second, we revealed that the link between HPWP and organizational innovativeness was partially mediated by employee relational coordination competencies, indicating the importance of coordination and cooperation in today's fast-paced business environment. Our findings contribute to the growing research interest in understanding the mechanisms that associate HPWP and organizational outcomes [6,7,46]. Moreover, we fill the gap in the literature by uncovering the role HPWP and relational coordination competencies play in organizational innovativeness, a critical yet unanswered question. Our finding is highly relevant, given current business interests in innovation as a means to seize new opportunities to grow and outperform global competitors [47]. A relevant notion is the innovation capability of the firm, which refers to the ability to mobilize and combine existing knowledge to create new knowledge [48]. Employee relational coordination competencies characterized by sharing of goals and knowledge with mutual respect and effective communication, have the potential to provide a solid basis for a firm's innovation capability. Future research may extend the present study by exploring how employee collaborative effort and relational coordination competencies lead to different kinds of organizational outcomes such as productivity or voluntary turnover rate.

Finally, consistent with the contingency [17] as well as the interactional perspective [18], our findings show how contextual factors influence the effects of HPWP on organizational innovativeness. Although external situational factors such as market turbulence are known to have a profound impact on organizations, our understanding of its interactive effects with HPWP has been limited both theoretically and empirically. The present study took a step toward filling the gap by showing a positive moderation effect of market turbulence on the relationship between HPWP and organizational innovativeness. We encourage researchers to further investigate additional external or internal contingencies that influence the effectiveness of HPWP. For example, economies with an open-innovation orientation are likely to create a business environment that fosters firms' innovative efforts. Start-ups, small and medium-sized enterprises, or social entrepreneurs with governmental support may innovate through open connections [49]. In such economies, the link between HPWP and organizational innovativeness may become stronger. In addition, government policies on work-life balance [50] can be suggested as potential moderators. The implementation of flexible time arrangements or parental leave policies may be more effective when combined with the government's legal support and policies for employee work-life balance, leading to increased levels of employee well-being, satisfaction, and organizational productivity. 


\subsection{Practical Implications}

Our findings have implications for business practice. Given that innovations often require cross-team or cross-departmental collaboration to succeed, employee engagement in collaborative effort becomes crucial in organizational innovative processes. Hence, managers need to pay greater attention to the human resource practices that facilitate coordination and collaboration. For instance, the practices of job rotation and decentralized decision-making are likely to foster knowledge and information sharing $[4,13,51]$, which speeds up the idea development and implementation activities. Team-based training and collective brainstorming sessions can also nurture skills and competencies required for collaborative tasks [33]. Indeed, innovation researchers have suggested that implementation and generation of innovative practices and products can be maximized by HR practices that reinforce cross-functional collaborative opportunities and skills [39,52].

More generally, a growing number of studies recommend ways to attain intended organizational goals through relational coordination practices and employee competencies. Structural interventions such as measuring team performance and developing shared information systems, as well as work process interventions including proactive conflict resolution and collective assessment of the current state, are some of the examples [53,54].

\subsection{Limitations and Future Research Directions}

The current study is not without limitations, which suggest interesting avenues for future research. First, our measurement of employee relational coordination competencies consisted of three items (i.e., communication, resource utilization and interpersonal skills) that focus on a set of skills and competencies potentially developed and nurtured through the relational coordination interactions and relationships. Although the three-item competency measurement is grounded on the key components of relational coordination such as effective communication and mutual respect that enable effective use of organizational resources [12], future research may try to reflect the full seven components of relational coordination (i.e., knowledge and goal sharing skills, accurate communication skills, etc.) in the measure.

Second, organizational innovativeness as the outcome variable can be criticized as being a distal indicator of the effects of relational coordination competencies. Prior studies on relational coordination have assessed its impact mostly on operational outcomes such as productivity and quality on the rationale that such interactions are likely to be present at the workplace level rather than at the organization level [46]. However, because the current study adopts a longitudinal approach with firms as our unit of analysis and HPWP operative at the firm level, the level of relational coordination competencies and the resulting level of innovativeness are expected to be different across different firms [53]. Nevertheless, it would be an interesting research avenue to explore how everyday relational coordination routines influence proximal outcomes that indicate innovativeness at the operational level.

Third, although we studied market turbulence as a moderator indicating the strategic orientation of the firm, one may argue that it can be viewed as an antecedent of HPWP. In other words, the extent of firm value put on market competitiveness and innovativeness can determine the degree of financial resources and commitment for the implementation of HPWP with a relational coordination focus. Indeed, it has been suggested that business and strategic initiatives tend to influence the design of HRM systems [55]. Hence, future research may empirically test market turbulence or firms' strategic orientations as a triggering factor that leads to the implementation of HPWP.

Finally, the study sample mainly consisted of manufacturing firms with R\&D units in Korea. Although our research was conducted in a setting where relational coordination competencies and organizational innovativeness were relevant and critical, subsequent studies may be conducted in other cultural or industrial contexts to corroborate the external validity of the findings. 
Author Contributions: Conceptualization, S.-Y.R. and H.-D.S.; methodology, J.P.; formal analysis, J.P.; writing-original draft preparation, S.-Y.R.; writing—review and editing, S.-Y.R. and H.-D.S. All authors have read and agreed to the published version of the manuscript.

Funding: This work was supported by 2020 Hongik University Research Fund.

Conflicts of Interest: The authors declare no conflict of interest.

\section{References}

1. Messersmith, J.G.; Guthrie, J.P. High performance work systems in emergent organizations: Implications for firm performance. Hum. Resour. Manag. 2010, 49, 244-266. [CrossRef]

2. Polyhart, R.E.; Moliterno, T.P. Emergence of the human capital resource: A multilevel model. Acad. Manag. Rev. 2011, 35, 127-150. [CrossRef]

3. Zacharatos, A.; Barling, J.; Iverson, R.E. High-performance work systems and occupational safety. J. Appl. Psychol. 2005, 90, 77-93. [CrossRef] [PubMed]

4. Huselid, M.A. The impact of human-resource management-practices on turnover, productivity, and corporate financial performance. Acad. Manag. J. 1995, 38, 635-672.

5. Ichniowski, C.; Shaw, K.; Prennushi, G. The effects of human resource management practices on productivity: A study of steel finishing lines. Am. Econ. Rev. 1997, 87, 291-313.

6. Gittell, J.H.; Seidner, R.; Wimbush, J. A relational model of how high-performance work systems work. Organ. Sci. 2010, 21, 490-506. [CrossRef]

7. Jiang, K.; Lepak, D.P.; Hu, J.; Baer, J.C. How does human resource management influence organizational outcomes? A meta-analytic investigation of mediating mechanisms. Acad. Manag. J. 2012, 55, 1264-1294. [CrossRef]

8. Lepak, D.P.; Snell, S.A. Examining the human resource architecture: The relationships among human capital, employment, and human resource configurations. J. Manag. 2002, 28, 517-543. [CrossRef]

9. Takeuchi, R.; Lepak, D.P.; Wang, H.; Takeuchi, K. An empirical examination of the mechanisms mediating between high-performance work systems and the performance of Japanese organizations. J. Appl. Psychol. 2007, 92, 1069-1083. [CrossRef]

10. Grant, R.M. Prospering in dynamically competitive environments: Organizational capability as knowledge integration. Organ. Sci. 1996, 7, 375-387. [CrossRef]

11. Kogut, B.; Zander, U. What firms do? Coordination, identity, and learning. Organ. Sci. 1996, 7, 502-518. [CrossRef]

12. Gittell, J.H. High Performance Healthcare: Using the Power of Relationships to Achieve Quality, Efficiency and Resilience; McGraw-Hill: New York, NY, USA, 2009; ISBN 9780071621762.

13. Cramm, J.M.; Nieboer, A.P. Relational coordination promotes quality of chronic care delivery in Dutch disease-management programs. Health Care Manag. Rev. 2012, 37, 301-309. [CrossRef] [PubMed]

14. Gittell, J.H. Coordinating mechanisms in care provider groups: Relational coordination as a mediator and input uncertainty as a moderator of performance effects. Manag. Sci. 2002, 48, 1408-1426. [CrossRef]

15. Laursen, K.; Foss, N.J. New human resource management practices, complementarities and the impact on innovation performance. Camb. J. Econ. 2003, 27, 243-263. [CrossRef]

16. Stock, R.M.; Totzauer, F.; Zacharias, N.A. A closer look at cross-functional R\&D cooperation for innovativeness: Innovation-oriented leadership and human resource practices as driving forces. J. Prod. Innov. Manag. 2014, 31, 924-938.

17. Delery, J.E.; Doty, D.H. Modes of theorizing in strategic human resource management. Acad. Manag. J. 1996, 39, 802-835.

18. Pfeffer, J. New Directions for Organization Theory: Problems and Prospects; Oxford University Press: Oxford, UK, 1997; ISBN 0195114345.

19. Santos-Vijande, M.L.; Álvarez-González, L.I. Innovativeness and organizational innovation in total quality oriented firms: The moderating role of market turbulence. Technovation 2007, 27, 514-532. [CrossRef]

20. MacDuffie, J.P. Human resource bundles and manufacturing performance: Organizational logic and flexible production systems in the world auto industry. Indust. Labor Relat. Rev. 1995, 48, 197-221. [CrossRef]

21. Pfeffer, J. The Human Equation: Building Profits by Putting People First; Harvard Business School Press: Boston, MA, USA, 1998; ISBN 9780875848419. 
22. Cabello-Medina, C.; Lopez-Cabrales, A.; Valle-Cabrera, R. Leveraging the innovative performance of human capital through HRM and social capital in Spanish firms. Intern. J. Hum. Resour. Manag. 2011, 22, 807-828. [CrossRef]

23. Gittell, J.H. Relationships between service providers and their impact on customers. J. Serv. Res. 2002, 4, 299-311. [CrossRef]

24. Gant, J.; Ichniowski, C.; Shaw, K. Social capital and organizational change in high-involvement and traditional work organizations. J. Econ. Manag. Strateg. 2002, 11, 289-328. [CrossRef]

25. Collins, C.J.; Clark, K.D. Strategic human resource practices, top management team social networks, and firm performance: The role of human resource practices in creating organizational competitive advantage. Acad. Manag. J. 2003, 46, 740-751.

26. Sun, L.-Y.; Aryee, S.; Law, K.S. High-performance human resource practices, citizenship behavior and organizational performance: A relational perspective. Acad. Manag. J. 2007, 50, 558-577. [CrossRef]

27. Wright, P.M.; Gardner, T.M.; Moynihan, L.M. The impact of HR practices on the performance of business units. Hum. Resour. Manag. J. 2003, 13, 21-36. [CrossRef]

28. Menguc, B.; Auh, S. Creating a firm-level dynamic capability through capitalizing on market orientation and innovativeness. J. Acad. Mark. Sci. 2006, 34, 63-73. [CrossRef]

29. Carlile, P.R. Transferring, translating, and transforming: An integrative framework for managing knowledge across boundaries. Organ. Sci. 2004, 15, 555-568. [CrossRef]

30. Daft, R.L.; Lengel, R.H. Organizational information requirements, media richness and structural design. Manag. Sci. 1986, 32, 554-571. [CrossRef]

31. Gittell, J.H.; Douglass, A. Relational bureaucracy: Structuring reciprocal relationships into roles. Acad. Manag. Rev. 2012, 37, 709-733. [CrossRef]

32. Tjosvold, D. Making a technological innovation work: Collaboration to solve problems. Hum. Relat. 1990, 43, 1117-1131. [CrossRef]

33. Combs, J.; Liu, Y.; Hall, A.; Ketchen, D. How much do high-performance work practices matter? A meta-analysis of their effects on organizational performance. Pers. Psychol. 2006, 59, 501-528. [CrossRef]

34. Wang, G.; Dou, W.; Zhu, W.; Zhou, N. The effects of firm capabilities on external collaboration and performance: The moderating role of market turbulence. J. Bus. Res. 2015, 68, 1928-1936. [CrossRef]

35. Hurley, R.F.; Hult, T.M. Innovation, market orientation, and organizational learning: An integration and empirical examination. J. Mark. 1998, 62, 42-54. [CrossRef]

36. Sahoo, S. Quality management, innovation capability and firm performance: Empirical insights from Indian manufacturing SMEs. TQM J. 2019, 31, 1003-1027. [CrossRef]

37. Baron, R.M.; Kenny, D.A. The moderator-mediator variable distinction in social psychological research: Conceptual, strategic, and statistical considerations. J. Pers. Soc. Psychol. 1986, 51, 1173-1182. [CrossRef] [PubMed]

38. Hayes, A.F.; Preacher, K.J. Statistical mediation analysis with a multicategorical Independent variable. $\mathrm{Br}$. J. Math. Stat. Psychol. 2014, 67, 451-470. [CrossRef] [PubMed]

39. Zeng, J.; Phan, C.A.; Matsui, Y. The impact of hard and soft quality management on quality and innovation performance: An empirical study. Intern. J. Prod. Econ. 2015, 162, 216-226. [CrossRef]

40. Yun, J.J.; Liu, Z. Micro-and macro-dynamics of open innovation with a quadruple-helix model. Sustainability 2019, 11, 3301. [CrossRef]

41. Gittell, J.H. Relationship and resilience: Care provider responses to pressures from managed care. J. Appl. Behav. Sci. 2008, 44, 25-47. [CrossRef]

42. Gittell, J.H.; Weinberg, D.; Bennett, A.; Miller, J. Is the doctor in? A relational approach to job design and the coordination of work. Hum. Resour. Manag. 2008, 47, 729-755. [CrossRef]

43. Noel, P.; Lanham, H.; Palmer, R.; Leykhum, L.; Parchman, M. The importance of relational coordination and reciprocal learning for chronic illness care in primary care teams. Health Care Manag. Rev. 2013, 38, $20-28$. [CrossRef]

44. Havens, D.S.; Gittell, J.H.; Vasey, J. Impact of relational coordination on nurse job satisfaction, work engagement and burnout: Achieving the quadruple aim. J. Nurs. Admin. 2018, 48, 132-140. [CrossRef] [PubMed]

45. Gittell, J.H. Organizing work to support relational coordination. Intern. J. Hum. Resour. Manag. 2000, 11, 517-539. [CrossRef] 
46. Siddique, M.; Procter, S.; Gittell, J.H. The role of relational coordination in the relationship between high-performance work systems (HPWS) and organizational performance. J. Organ. Eff. People Perf. 2019, 6, 246-266. [CrossRef]

47. Teece, D. Dynamic Capabilities and Strategic Management: Organizing for Innovation and Growth; Oxford University Press: Oxford, UK, 2009; ISBN 0199691908.

48. Adler, P.; Shenhar, A. Adapting your technological base: The organizational challenge. Sloan Manag. Rev. 1990, 32, 25-37.

49. Yun, J.J.; Won, D.; Park, K. Entrepreneurial cyclical dynamics of open innovation. J. Evol. Econ. 2018, 28, 1151-1174. [CrossRef]

50. Lomazzi, V.; Israel, S.; Crespi, I. Gender equality in Europe and the effect of work-family balance policies on gender-role attitudes. Soc. Sci. 2018, 8, 5. [CrossRef]

51. Acosta-Prado, J.C. Relationship between organizational climate and innovation capability in new technology-based firms. J. Open Innov. Technol. Mark. Complex. 2020, 6, 28. [CrossRef]

52. Schniederjans, D.; Schniederjans, M. Quality management and innovation: New insights on a structural contingency framework. Intern. J. Qual. Innov. 2015, 1, 1-20. [CrossRef]

53. Gittell, J.H. Transforming Relationships for High Performance: The Power of Relational Coordination; Stanford University Press: Palo Alto, CA, USA, 2016; ISBN 0804787018.

54. Perloff, J.; Rushforth, A.; Welch, L.C.; Daudelin, D.; Suchman, A.L.; Gittell, J.H.; Selker, H.P. Intervening to enhance collaboration in translational research: A relational coordination approach. J. Clin. Transl. Sci. 2017, 1, 218-225. [CrossRef]

55. Becker, B.E.; Huselid, M.A.; Pickus, P.S.; Spratt, M.F. HR as a source of shareholder value: Research and recommendations. Hum. Resour. Manag. 1997, 36, 39-47. [CrossRef]

(C) 2020 by the authors. Licensee MDPI, Basel, Switzerland. This article is an open access article distributed under the terms and conditions of the Creative Commons Attribution (CC BY) license (http://creativecommons.org/licenses/by/4.0/). 